\title{
Digital surface models are not always representative of former glacier beds: palaeoglaciological and geomorphological implications
}

\author{
Andrew Finlayson ${ }^{\mathrm{a}, \mathrm{b}, *}$ \\ ${ }^{a}$ British Geological Survey, Murchison House, West Mains Road, Edinburgh, UK, EH93LA \\ ${ }^{b}$ Institute of Geography, University of Edinburgh, Edinburgh, UK, EH89XP
}

\begin{abstract}
Quantitative palaeoglaciological studies that use digital surface models (DSMs) may be subject to error because former glacier beds are not always accurately represented. This is because the Earth's surface may have changed significantly since deglaciation. This paper evaluates potential errors caused by postglacial sedimentation, by comparing the results of physical palaeoglaciological reconstructions and bedform morphometric analyses in parts of Scotland, using both the modern land surface and interpolated former glacier beds derived from borehole data. For a former terrestrial outlet glacier, removal of postglacial sediments increases the modelled ice surface elevation and ice thickness by $0.7 \%$ and $5 \%$, respectively, over a $27-\mathrm{km}$ flow line. For a former tidewater glacier, the reconstructed steady state ice flux is increased by $250 \%$ when the modern land/seabed surface is replaced with an interpolated former glacier bed. In a classical drumlinised landscape, removal of postglacial sediments affects bedform morphometrics, with an increase in measured drumlin length, width, relief, and volume. The cases presented in this paper are from environments known to have experienced postglacial sedimentation. They provide situational examples of the degree of error that can be introduced when the modern land surface is used to represent former glacier beds in these environments. In some regions, sufficient subsurface data exists over large areas to create improved topographic representations of former glacier beds; these could form important inputs to the next generation of palaeo-ice-sheet and palaeo-glacier simulations.
\end{abstract}

Keywords: digital surface models, palaeoglaciology, glacier profile, calving, drumlins

*Corresponding author. Tel.: +44 131650 0209; Fax.: +44 1316681535

Email address: afin@bgs.ac.uk (Andrew Finlayson)

Preprint submitted to Geomorphology

March 26, 2013 


\section{Introduction}

Digital surface models (DSMs) can provide high resolution geomorphological information about the Earth's surface. They are used to represent past glacier beds for the reconstruction of former ice sheets (Lidmar-Bergstrőm et al., 1991; O'Cofaigh et al., 2009; Trommelen and Ross, 2010), numerical palaeo-glacier simulations (Plummer and Phillips, 2003; Golledge et al., 2008) and statistical analyses of glacier bedform morphometrics (Dunlop and Clark, 2006; Clark et al., 2009; Hess and Briner, 2009). When using DSMs, geomorphologists have to assess the risk of any land surface change, in the time between glacier ice occupation and capture of elevation data, having affected the geomorphic expression of the former glacier bed. Commonly, these changes are too small to introduce significant error to conceptual palaeoglaciological reconstructions. However, the importance of bed topography to numerical simulations and quantitative morphometric assessments could make them prone to errors if the land surface has been considerably lowered by erosion or raised by sediment deposition after glacier retreat. In lowland and coastal areas, high rates of sedimentation have been shown to accompany, and immediately follow, deglaciation (Eyles et al., 1990; Cowan and Powell, 1991; Leventer et al., 2006), and some workers have recognised that sediment laid down after ice margin retreat (hereafter referred to as postglacial sediment) may lead to errors in quantitative studies (Piotrowski and Tulaczyk, 1999; Golledge et al., 2012; Spagnolo et al., 2012). The goal of this paper is to test how the results of simple quantitative palaeoglaciological investigations differ when the topographic expression of postglacial sediments are removed from DSMs, thereby providing some indication of the error for a given set of examples.

Three case studies from parts of Scotland that were deglaciated ca. 15 ka BP (Fig. 1A) are presented. Reconstructed glacier characteristics and bedform morphometric analyses obtained using the modern land surface are compared with those derived from interpolated former glacier beds based on densely spaced borehole data. The first case considers differences in valley shape and the effects on a glacier surface profile calculated using an iterative flowline model in the Clyde basin, west-central Scotland (Fig. 1B). The second 
case examines the differences in reconstructed calving rates and hypothetical ice fluxes at a former tidewater glacier margin in the Cromarty Firth, northeast Scotland (Fig. 1C). The third case compares three-dimensional morphometric measurements for a small sample of drumlins in southwest Glasgow (Fig. 1D). The examples are chosen from near-coastal areas known to have been subjected to postglacial sedimentation. Such environments are often included in palaeoglaciological studies, and coastal margins are recognised as key dynamic zones of past ice sheets. Therefore a requirement exists to quantitatively evaluate potential errors that may be introduced into palaeoglaciological models and bedform measurements by unrepresentative DSMs in these areas.

\section{Study area and methods}

\subsection{Clyde basin: valley shape and former glacier profile}

The first study focuses on valley shape and reconstructed glacier surface profile in the Clyde basin, west-central Scotland (Fig. 1B) at the time when the Blantyreferme moraine was formed. During overall ice sheet retreat, the Blantyreferme moraine was constructed in the lower part of the Clyde basin by an outlet glacier, sourced from an ice cap centred over the Scottish Highlands (Price, 1975; Finlayson et al., 2010). Glacier flow at that time was toward the southeast. Final glacier decay in the lower Clyde basin was accompanied by relative sea level rise to almost $40 \mathrm{~m}$ above present when thick sequences of glaciomarine silts and clays were laid down, partially masking the former glacier bed (Browne and McMillan, 1989; Peacock, 2003).

In the Clyde basin, the former glacier bed was extracted from the three-dimensional geological model described by Finlayson (2012). The model (Fig. 2A) adheres to surface sediment distribution shown on 1:50,000-scale geological maps and subsurface data derived from 1260 borehole logs (Fig. 2B). It comprises a series of surfaces, representing the tops and bases of lithostratigraphic units, derived through triangulation of regularly spaced $x, y, z$ nodes along cross sections (total length $1860 \mathrm{~km}$ ) and 'envelopes,' which represent the lateral (surface and buried) extent of lithostratigraphic units. The model was calculated at a 500-m 
grid resolution. Postglacial lithostratigraphic units, representing $2.37 \mathrm{~km}^{3}$ of sediment, were removed to obtain an interpolated glacier bed, more closely representing bed topography at the time when the Blantyreferme moraine was formed (Fig. 2C). The interpolated former glacier bed is overdeepened and lies below the postglacial and modern sea level. The depth of the interpolated bed is therefore unlikely to have been enhanced by postglacial fluvial erosion.

The influence of postglacial sediments on glacial valley shape was examined in the lower part of the Clyde basin, using valley shape factor $(f)$. Shape factor is used to account for the part of a glacier's weight that is supported by the valley sidewalls; it defines the proportion of driving stress $\left(\tau_{D}\right)$ that is transferred to basal shear stress $\left(\tau_{B}\right)$ at the valley centre, so that $\tau_{B}=f \tau_{D}$. Driving stress is calculated from

$$
\tau_{D}=\rho_{I} g H \tan \alpha
$$

where $\rho_{I}$ is the density of glacier ice $\left(\sim 900 \mathrm{~kg} \mathrm{~m}^{-3}\right), g$ is gravitational acceleration (9.81 $\mathrm{m} \mathrm{s}^{-2}$ ), $H$ is glacier thickness (m) and $\alpha$ is glacier surface slope. For a flat bed (which presents no side drag), $f=1$, and for a semi-ellipse-shaped valley with a half-width equal to centre-line ice thickness $f=0.5$ (Paterson, 1994). Shape factor can be calculated from

$$
f=\frac{A}{H P}
$$

where $A$ is the cross-sectional area of the valley that is filled with glacier ice, and $P$ is the cross-sectional perimeter that is in contact with glacier ice. The approach adopted here is that used by Benn and Hulton (2010) in which $A$ is calculated along the cross section from

$$
A=\sum_{i=1}^{n} \frac{\left(\left(B_{M A X}-B_{i}\right)+\left(B_{M A X}-B_{i+1}\right)\right) \Delta y}{2}
$$

74 where $B$ is the glacier bed elevation, and $\Delta y$ is the horizontal step size across the valley. The value for $P$ is obtained from

$$
P=\sum_{i=1}^{n} \sqrt{\left(B_{i+1}-B_{i}\right)^{2}+(\Delta y)^{2}}
$$


To test the effect that removing the postglacial infill has on the reconstructed glacier profile, an iterative valley centre flowline model was applied:

$$
h_{i+1}^{2}-h_{i+1}\left(B_{i}+B_{i+1}\right)+h_{i}\left(B_{i+1}-H_{i}\right)-\frac{2 \Delta x\left(\tau_{B} / f\right)}{\rho_{I} g}=0
$$

where $h$ is ice surface elevation, and $x$ is the horizontal coordinate along the valley centre line. The solution to Eq. (5) is usefully described by Benn and Hulton (2010) who provide an accompanying spreadsheet program.

\subsection{Cromarty Firth: palaeo-calving speed and ice flux}

The Cromarty Firth (Fig. 1C) is a long marine inlet in northeast Scotland that was a tributary to the former Moray Firth Ice Stream (MFIS) (Merritt et al., 1995). Former ice flow in the area was toward the northeast, broadly parallel to the alignment of the Cromarty Firth. During deglaciation, calving ice fronts of the MFIS retreated into the Cromarty and Inverness Firths when relative sea level was at least $\sim 30 \mathrm{~m}$ above present (Peacock, 1974; Firth, 1990; Merritt et al., 1995; Turner et al., 2012). Following glacier withdrawal, deposits of glaciomarine and marine sediments exceeding $60 \mathrm{~m}$ in thickness were laid down in the Cromarty Firth (Peacock, 1974).

The former glacier bed was manually interpolated along a single cross section using borehole logs and descriptions from Peacock (1974). The section line is approximately normal to former glacier flow direction as ice retreated into the Cromarty Firth during deglaciation (Firth, 1990; Merritt et al., 1995) (Fig. 3A and B).

To examine the effect that removal of postglacial sediments has on palaeo-calving speed $\left(U_{C}\right)$ in the Cromarty Firth, an empirically derived water depth $\left(D_{W}\right)$ relation was used (Brown et al., 1983; Pelto and Warren, 1991):

$$
U_{C}=70+8.33 D_{W}
$$

7 ets 99

Although more robust, physically based calving laws now exist (Benn et al., 2007; Nick et al., 2010), they require input variables not easily obtained from the palaeorecord. The water depth relation used here describes real calving rates in many instances (Hooke, 2005), 
and its simplicity allows it to be employed in numerical models with minimal computation (Golledge et al., 2008).

Ice thickness at the calving palaeoglacier margin $\left(H_{C}\right)$ is calculated based on the floatation criterion used by Vieli et al. $(2001,2002)$, in which the calving margin is located where the glacier approaches floatation thickness. $H_{C}$ can be calculated from

$$
H_{C}=(1+q) \frac{\rho_{S W}}{\rho_{I}} D_{W}
$$

where $q$ is a fraction representing the height of the ice front above buoyancy at the calving margin, and $\rho_{S W}$ is the density of sea water $\left(1030 \mathrm{~kg} \mathrm{~m}^{-1}\right)$. A value of 0.15 is adopted for $q$ (Vieli et al., 2001). Application of Eq. (7) enables cross-sectional area $\left(A_{C}\right)$ of the calving margin to be calculated (Fig. 3C). Depth-averaged velocity $(U)$ at the ice front is given by the equation

$$
U=U_{C}-Q_{M}+\frac{\Delta L}{\Delta t}
$$

where $Q_{M}$ is ice loss caused by melting, $L$ is glacier length, and $t$ is time. Under steady state conditions $\Delta L / \Delta t=0$. Assuming negligible melt, ice flux $\left(Q_{I}\right)$ at the calving margin can be calculated from

$$
Q_{I}=U_{C} A_{C}
$$

\subsection{Southwest Glasgow: drumlin morphometric analyses}

The third example focuses on morphometric measurements of drumlins in southwest Glasgow (Fig. 1D). The lower Clyde basin is well known for its drumlins, which have been included in several regional and national morphometric data sets (Menzies, 1996; Clark et al., 2009; Finlayson et al., 2010; Spagnolo et al., 2012). Many of these drumlins occur in areas inundated by the Lateglacial sea following deglaciation of the Glasgow area and are partially overlain by glaciomarine deposits (Peacock, 2003; Finlayson et al., 2010).

For a $6.1-\mathrm{km}^{2}$ area in southwest Glasgow, the glacier bed was interpolated at a 25m grid spacing using ordinary kriging, based on bed surface points interpreted from 144 borehole records (Fig. 4). The surface of the former glacier bed was readily distinguished in borehole logs from contrasting sedimentary and geotechnical properties between glacial 
till or bedrock and the overlying, generally soft, raised marine silts and clays. One hundred regularly spaced additional points were added where glacial till is shown at the modern land surface on digital geological maps (1:10,000 scale DiGMapGB-10) prior to kriging in order to achieve a uniform spatial distribution of control points. These additional points were sampled from the Intermap Technologies NEXTMap Britain elevation data set (5-m horizontal resolution subsampled to $25 \mathrm{~m}$ ). Areas where till is shown at the modern surface in geological maps were then removed from the surface produced by kriging and replaced with extracts from the NEXTMap data set. The result is a single DSM that better represents the former glacier bed (Fig. 4).

To test the extent to which removal of postglacial sediments affects the results of glacier bedform analysis, drumlin morphometrics were examined using the modern land surface and interpolated glacier bed in southwest Glasgow (Fig. 4). Drumlin length, width, relief, area, and volumes were measured. Measurement of drumlin relief followed the method of Spagnolo et al. (2012), whereby a planar drumlin base was interpolated from its outline (identified by break in slope). The maximum vertical difference $(a)$ between drumlin surface and the planar base (dipping at slope angle, $\theta$ ) can be used to define drumlin relief $(r)$ where

$$
r=a \sin (90-\theta)
$$

Drumlin volume was calculated by combining the triangulated drumlin surfaces and drumlin bases to form solid objects comprising numerous tetrahedrons whose volumes were summed.

\section{Results}

\subsection{Valley shape and reconstructed ice surface profile in the Clyde basin}

Valley shape factor and ice surface profiles were calculated for an outlet glacier in the lower Clyde basin at the position of the Blantyreferme moraine (Fig. 5). Shape factors calculated using both the modern land surface and the interpolated former glacier bed are shown in Fig. 5A. Removal of postglacial sediments causes a deepening of the cross valley profile and an increase in length of the cross valley perimeter. As a result the calculated 
shape factors for six investigated cross profiles are reduced by $2 \%-18 \%$. The reconstructed ice surface profiles and ice thickness are shown in Fig. 5B and C. For the purposes of the reconstruction, a constant basal shear stress of $25 \mathrm{kPa}$ was assumed; this is consistent with inferences of relatively low effective pressures during deglaciation in the lower Clyde basin (Finlayson, 2012). The overall effect of removing postglacial sediments in this example is relatively small, and the reconstructed ice surfaces closely follow each other (Fig. 5B). The reconstructed ice surface slope derived from the interpolated glacier bed, however, is slightly steeper, compensating for the greater proportion of driving stress supported by valley sides (shown by the shape factor calculations). This increase is largely offset by the lower bed elevation of the interpolated surface. Best fit lines over the whole $27-\mathrm{km}$ flow line show that the reconstructed ice surface elevation is $0.7 \%$ greater and the reconstructed ice thickness is $5 \%$ greater when modelled using the interpolated glacier bed (Fig. 5D and E).

\subsection{Reconstructed calving rate and ice flux in the Cromarty Firth}

Figure 3C illustrates the reconstructed glacier cross sections at the hypothetical calving margin in the Cromarty Firth, based on the modern land / seabed surface and the interpolated glacier bed. Removal of postglacial sediment effectively doubles the cross-sectional area of the glacier. Furthermore, based on the water-depth relation, calculated width-averaged calving speed for the glacier increases by $74 \%$, resulting in an $\sim 250 \%$ increase in steady state ice flux (Table 1). The removal of postglacial sediments also exposes more of the valley sides (the shape factor reduces from 0.7 to 0.5 ), which would increase drag and have implications for the necessary driving stresses.

\subsection{Drumlin morphometrics in southwest Glasgow}

The morphometric characteristics for five sample drumlins, derived from the modern land surface and from the interpolated glacier bed, are given in Table 2. Drumlins were delimited by their breaks in slope (Fig. 6). Using the modern surface model, a clear break in slope was apparent allowing straightforward, objective identification of each drumlin perimeter. However, breaks of slope are not as clear for the interpolated glacier bed (Fig. 6). This 
may partially result from the kriging procedure, which like many interpolation techniques has a tendency to underestimate highs and overestimate lows. It may also be that some of these particular drumlins having wave-like, rather than blister-like long profiles (Spagnolo et al., 2012) (far larger sample populations would be required to investigate this further). As a result, delimiting the perimeter of drumlins from the interpolated glacial land surface is slightly more subjective.

For drumlins 1, 2, 3, and 4, all morphometric characteristics increase following removal of postglacial sediments, resulting in volume increases of $37 \%-119 \%$. Drumlin 5 is not affected because its interpreted perimeter lies beyond the extent of any modelled postglacial sediment infill.

The drumlins in this study have relatively low elongation ratios (ERs) $(<1.7)$. However, their morphometric characteristics are within the range identified by Clark et al. (2009) for drumlins in Britain. The undulating topography of the inter-drumlin area on the interpolated glacier bed reveals a subtle ridge linking drumlins 1, and 4 (Fig. 6). Some of these drumlins may represent the upper parts of larger, ribbed-moraine-like features, which have been identified elsewhere in the Clyde basin Finlayson et al. (2010), and this could perhaps explain the relatively low ERs. However, a far larger sample area and data set would be required to test if this is the case.

\section{Discussion}

The examples given in this paper focus exclusively on the influence of postglacial sedimentation upon a set of palaeoglaciological reconstructions and bedform morphometric measurements, which are based on analysis of the land surface. However, no account is made for postglacial erosion of parts of the bed. While the influence of erosion is expected to have been minimal in these largely depositional lowland settings, it is noted as an unknown source of error that is not included in this study.

The results demonstrate that removal of postglacial sediments from the land surface can affect the outcomes of investigations by varying amounts. In the Clyde basin, despite the thickness of postglacial sediments (up to $35 \mathrm{~m}$ ), ice surface elevations reconstructed 
using the flowline model are only slightly affected (0.7\% difference). Similar flowline models are often used in palaeo-glacier and palaeo-ice-cap reconstructions (Locke, 1995; Rea and Evans, 2007; Finlayson et al., 2011; Hughes et al., 2011), and the results presented here demonstrate one case where error introduced by postglacial sediment fill is relatively small. However, ice thickness variations resulting from postglacial sediment removal $(\sim 5 \%$ over the 25-km flowline in the lower Clyde basin) may have a significant bearing on ice volume estimates, particularly where numerous in-filled valleys are included within a study.

Of the examples presented here, the effects of postglacial sediment removal on the reconstructed calving glacier in the Cromarty Firth are perhaps the most significant, with large increases in both reconstructed calving speed and the required steady state ice flux. The thick sequences of deglacial and postglacial sediments in the Cromarty Firth are not unique. In fact, they may be the norm. For example, around the Scottish coastline postglacial sediments reach $47 \mathrm{~m}$ in the inner Moray Firth (Andrews et al., 1990), > $50 \mathrm{~m}$ in parts of the Firth of Forth (B.G.S., 1987), 50-70 m in outer Loch Broom (Stoker et al., 2006), and $>100 \mathrm{~m}$ in parts of the outer Firth of Clyde (B.G.S., 1985). Removal of thick postglacial sediments from near-shore former ice-marginal environments could have an influence on the behaviour of numerical palaeo-glacier models, significantly increasing rates of simulated ice loss. This is one possible explanation for mismatches that sometimes occur when comparing simulated glaciers with empirical data. However, such influences may be restricted to near-shore environments as postglacial sediments tend to reduce in thickness farther offshore (Andrews et al., 1990), as indicated by the expression of glacial landforms on the seabed surface (Bradwell et al., 2008; Bjarnadóttir et al., in press).

The drumlin examples from southwest Glasgow comprise only a very small sample population - similar high resolution geostatistical interpolations over a larger area would be time consuming and require adequate, well-distributed subsurface data sets. However, the results are of note because they illustrate real examples where true drumlin morphology probably differs from that indicated by modern DSMs. Approximately $170 \mathrm{~km}^{2}$ of the drumlinised lower Clyde basin is mantled by postglacial raised marine deposits, suggesting that a much larger number of drumlin measurements there could be affected. Geological maps of the UK 
indicate several coastal and lowland areas where glacier bedforms and mapped sequences of postglacial sediments (e.g., raised marine deposits, glaciolacustrine deposits, glaciofluvial deposits) occur together, with the possibly that summary statistics of drumlin morphometry based on national data sets (Clark et al., 2009; Spagnolo et al., 2012) could be influenced. Outside those areas, however, the morphometries of glacial bedforms are less likely to differ, as shown by the unaffected characteristics of drumlin 5 (Table 2), at the margin of the modelled postglacial infill, although other processes not considered here (e.g. colluvial activity) may still have affected drumlin shape.

A further point to note from the Glasgow example is the increase in overall land surface relief when postglacial sediments are removed. The present day true land surface area (based on a triangulated land surface at $25-\mathrm{m}$ resolution) in the southwest Glasgow study area is $6.144 \mathrm{~km}^{2}$. Removal of postglacial sediments results in an increased former glacier bed area of $6.162 \mathrm{~km}^{2}$, highlighting the smoothing effect that postglacial sediments have on the landscape. While the increase in area is small in this example, it is a useful illustration of how parameters such as glacier bed roughness, which is linked to glacier velocity, can be affected by removal of postglacial sediments in palaeoglaciological studies.

This study has demonstrated how palaeoglaciological reconstructions and bedform morphometric analyses can vary if postglacial sediments are removed. The examples use high resolution surface analysis at local to regional scales. Whether accounting for postglacial sediment infill would significantly affect the results of larger scale (and perhaps lower resolution) studies is difficult to ascertain. High resolution DSMs are becoming increasingly available, and numerical ice sheet simulations can now be performed using anisotropic meshes with high spatial resolution at dynamic zones (Seddik et al., 2012). Therefore, the influence of (and potential error caused by) postglacial sediments in palaeoglaciological analyses is likely to become more important. The British palaeo-ice sheet has been described as a 'conceptual playground for glaciologists' (Boulton, 2012). In mainland and coastal Britain, large subsurface data sets exist ( $>600,000$ borehole records), providing the potential to create surfaces that more closely represent former glacier bed topography. This raises the question: should the next generation of palaeo-ice sheet simulations that include lowland and coastal 
areas be performed using the modern land surface topography or interpolated glacier bed topography? If the former is chosen, some inherent error will exist.

\section{Conclusions}

- Borehole data sets were used to interpolate former glacier beds in three lowland and coastal areas of Scotland. These former glacier beds differ in elevation and relief from the modern land surface, which includes the topographic expression of postglacial sediments.

- In the lower Clyde basin, removal of postglacial sediments results in a deepening of the valley and reduction in valley shape factor. The effects on a reconstructed $27-\mathrm{km}$ long glacier profile are that the ice surface slope is steepened, surface elevations are increased by $0.7 \%$, and glacier thickness is increased by $5 \%$.

- In the Cromarty Firth, removal of postglacial shallow seabed sediments doubles the reconstructed cross-sectional area at a former calving glacier margin. Reconstructed width-averaged calving speed is increased by $74 \%$, resulting in a $250 \%$ increase in the required steady-state ice flux.

- In the Glasgow area, removal of postglacial sediments results in an increase in measured drumlin length, width, and relief, causing an increase in drumlin volume of between $37 \%$ and $119 \%$.

- The examples presented in this paper were chosen from lowland and coastal areas where thick postglacial sediments were known to be present. These environments form significant components of formerly glaciated terrains, and the examples presented here demonstrate how physical palaeoglaciological reconstructions and statistical analyses of glacier bedform morphometrics can be influenced by postglacial sediments. Thick sequences of postglacial sediments may provide one explanation for mismatches between simulated glaciers and empirical data in such areas. In some regions sufficient 
subsurface data sets exist over large areas to provide improved topographic representations of former glacier beds. These could be of great benefit to the next generation of palaeo-ice-sheet simulations.

\section{Acknowledgements}

Tom Bradwell, David Sugden, and Emrys Phillips are thanked for their helpful comments on an earlier version of this manuscript. The journal reviewers and the editor, Richard Marston, are thanked for their comments, which helped improve the paper. This work forms part of the British Geological Survey's (BGS) Geology and Landscape Scotland Programme and was also supported by BGS Training. This paper is published with the permission of the Executive Director of BGS (NERC).

\section{References}

Andrews, I., Long, D., Richards, P., Thomson, A., Brown, S., Chesher, J., McMormac, M., 1990. United Kingdom Offshore Regional Report: The Geology of the Moray Firth. British Geological Survey, London. Benn, D.I., Hulton, N.R., 2010. An ExcelTM spreadsheet program for reconstructing the surface profile of former mountain glaciers and ice caps. Computers and Geosciences 36, 605-610.

Benn, D.I., Warren, C.R., Mottram, R.H., 2007. Calving processes and the dynamics of calving glaciers. Earth-Science Reviews 82, 143-179.

B.G.S., 1985. Clyde. 1:25,000 Series: Sea Bed Sediments and Quaternary Geology. British Geological Survey, Keyworth, Nottingham.

B.G.S., 1987. Tay-Forth. 1:25,000 Series: Sea Bed Sediments and Quaternary Geology. British Geological Survey, Keyworth, Nottingham.

Bjarnadóttir, L.R., Rüther, D.C., Winsborrow, M.C.M., Andreassen, K., in press. Grounding-line dynamics during the last deglaciation of Kveithola, W Barents Sea, as revealed by seabed geomorphology and shallow seismic stratigraphy. Boreas .

Boulton, G., 2012. Reflections on a Quaternary litho-stratigraphy for Britain. Proceedings of the Geologists' Association 123, 677-678.

Bradwell, T., Stoker, M.S., Golledge, N.R., Wilson, C.K., Merritt, J.W., Long, D., Everest, J.D., Hestvik, O.B., Stevenson, A.G., Hubbard, A.L., Finlayson, A.G., Mathers, H.E., 2008. The northern sector of the last British Ice Sheet: maximum extent and demise. Earth-Science Reviews 88, 207-226. 
Brown, C., Sikonia, W., Post, A., Rasmussen, L., Meier, M., 1983. Two calving laws for grounded icebergcalving glaciers. Annals of Glaciology 56, 295.

Browne, M., McMillan, A., 1989. Quaternary Geology of the Clyde Valley. British Geological Survey Research Report SA/89/1. Keyworth, Nottingham.

Clark, C.D., Hughes, A.L., Greenwood, S.L., Spagnolo, M., Ng, F.S., 2009. Size and shape characteristics of drumlins, derived from a large sample, and associated scaling laws. Quaternary Science Reviews 28, $677-692$.

Cowan, A.A., Powell, R., 1991. Ice-proximal sediment accumulation rates in a temperate glacial fjord, southeastern Alaska, in: Anderson, J., Ashley, G. (Eds.), Glacial Marine Sedimentation: Palaeoclimatic Significance. Boulder, Colorado. volume 261 of Geological Society of America Special Publication, pp. $61-73$.

Dunlop, P., Clark, C.D., 2006. The morphological characteristics of ribbed moraine. Quaternary Science Reviews 25, 1668-1691.

Eyles, N., Mullins, H.T., Hine, A.C., 1990. Thick and fast; sedimentation in a Pleistocene fiord lake of British Columbia. Geology 18, 1153-1157.

Finlayson, A., 2012. Ice dynamics and sediment movement: last glacial cycle, Clyde basin, Scotland. Journal of Glaciology 58, 487-500.

Finlayson, A., Golledge, N., Bradwell, T., Fabel, D., 2011. Evolution of a Lateglacial mountain icecap in northern Scotland. Boreas 40, 536-554.

Finlayson, A., Merritt, J., Browne, M., Merritt, J., McMillan, A., Whitebread, K., 2010. Ice sheet advance, dynamics, and decay configurations: evidence from west central Scotland. Quaternary Science Reviews 29, 969-988.

Firth, C., 1990. Late-Devensian relative sea-level changes associated with the deglaciation of the Inverness Firth and Beauly Firths, in: Auton, C., Firth, C., Merritt, J. (Eds.), Beauly to Nairn: Field Guide. Quaternary Research Association, Cambridge, pp. 66-77.

Golledge, N.R., Hubbard, A., Sugden, D.E., 2008. High-resolution numerical simulation of Younger Dryas glaciation in Scotland. Quaternary Science Reviews 27, 888-904.

Golledge, N.R., Mackintosh, A.N., Anderson, B.M., Buckley, K.M., Doughty, A.M., Barrell, D.J., Denton, G.H., Vandergoes, M.J., Andersen, B.G., Schaefer, J.M., 2012. Last Glacial Maximum climate in New Zealand inferred from a modelled Southern Alps icefield. Quaternary Science Reviews 46, 30-45.

Hess, D.P., Briner, J.P., 2009. Geospatial analysis of controls on subglacial bedform morphometry in the New York Drumlin Field - implications for Laurentide Ice Sheet dynamics. Earth Surface Processes and Landforms 34, 1126-1135.

Hooke, R.L., 2005. Principles of Glacier Mechanics. 2nd edition. Cambridge University Press, Cambridge, 
UK.

Hughes, P., Woodward, J., van Calsteren, P., Thomas, L., 2011. The glacial history of the Dinaric Alps, Montenegro. Quaternary Science Reviews 30, 3393-3412.

Leventer, A., Domack, E., Dunbar, R., Pike, J., Stckley, C., Maddison, E., Bracheld, S., Manley, P., McClennen, C., 2006. Marine sediment record from the East Antarctic margin reveals dynamics of ice sheet recession. GSA Today 16, 4-10.

Lidmar-Bergstrőm, K., Elvhage, C., Ringberg, B., 1991. Landfroms in Skåne, South Sweden. Geografiska Annaler. Series A. Physical Geography 73, 61-91.

Locke, W.W., 1995. Modelling of icecap glaciation of the northern Rocky Mountains of Montana. Geomorphology 14, 123-130.

Menzies, J., 1996. Glasgow's drumlins. Scottish Geographical Magazine 112, 188-193.

Merritt, J.W., Auton, C.A., Firth, C.R., 1995. Ice-proximal glaciomarine sedimentation and sea-level change in the Inverness area, Scotland: a review of the deglaciation of a major ice stream of the British Late Devensian ice sheet. Quaternary Science Reviews 14, 289-329.

Nick, F., van der Veen, C., Vieli, A., Benn, D., 2010. A physically based calving model applied to marine outlet glaciers and implications for the glacier dynamics. Journal of Glaciology 56, 781-794.

O’Cofaigh, C., Evans, D.J., Smith, I.R., 2009. Large-scale reorganization and sedimentation of terrestrial ice streams during late Wisconsinan Laurentide Ice Sheet deglaciation. Bulletin of the Geological Society of America 122, 743-756.

Paterson, W., 1994. The Physics of Glaciers. 3rd edition. Elsevier, Oxford, UK.

Peacock, J., 1974. Borehole evidence for late and post-glacial events in the Cromarty Firth, Scotland. Bulletin of the Geological Survey of Great Britain 48, 55-67.

Peacock, J.D., 2003. Late Quaternary sea level change and the raised marine deposits of the western highland boundary - A) the deglaciation of the lower Clyde valley: a brief review, in: Evans, D. (Ed.), The Quaternary of the Western Highland Boundary: Field Guide. Quaternary Research Association, London, UK, pp. 30-41.

Pelto, M., Warren, C., 1991. Relationship between tidewater calving velocity and water depth at the calving front. Annals of Glaciology 15, 781-794.

Piotrowski, J.A., Tulaczyk, S., 1999. Subglacial conditions under the last ice sheet in northwest Germany: ice-bed separation and enhanced basal sliding? Quaternary Science Reviews 18, 737-751.

Plummer, M.A., Phillips, F.M., 2003. A 2-D numerical model of snow/ice energy balance and ice flow for paleoclimatic interpretation of glacial geomorphic features. Quaternary Science Reviews 22, 1389-1406.

Price, R., 1975. The glaciation of west central Scotland - a review. Scottish Geographical Magazine 91, $134-145$. 
Rea, B.R., Evans, D.J., 2007. Quantifying climate and glacier mass balance in north Norway during the Younger Dryas. Palaeogeography, Palaeoclimatology, Palaeoecology 246, 307-330.

Seddik, H., Greve, R., Zwinger, T., Gillet-Chaulet, F., Gagliardini, O., 2012. Simulations of the Greenland ice sheet 100 years into the future with the full Stokes model Elmer/ice. Journal of Glaciology 58, 427-440. Spagnolo, M., Clark, C.D., Hughes, A.L., 2012. Drumlin relief. Geomorphology 153-154, 179-191.

Stoker, M., Bradwell, T., Wilson, C., Harper, C., Smith, D., Brett, C., 2006. Pristine fjord landsystem revealed on the sea bed in the Summer Isles region, NW Scotland. Scottish Journal of Geology 42, 89-99.

Trommelen, M., Ross, M., 2010. Subglacial landforms in northern Manitoba, Canada, based on remote sensing. Journal of Maps 2010, 618-638.

Turner, A.J., Woodward, J., Dunning, S.A., Shine, A.J., Stokes, C.R., Cofaigh, C.Ó., 2012. Geophysical surveys of the sediments of Loch Ness, Scotland: implications for the deglaciation of the Moray Firth Ice Stream, British-Irish Ice Sheet. Journal of Quaternary Science 27, 221-232.

Vieli, A., Funk, M., Blatter, H., 2001. Flow dynamics of tidewater glaciers: a numerical modelling approach. Journal of Glaciology 47, 595-606.

Vieli, A., Jania, J., Kolondra, L., 2002. The retreat of a tidewater glacier: observations and model calculations on Hansbreen, Spitsbergen. Journal of Glaciology 48, 592-600. 


\section{List of Figures}

Fig. 1. (A) Location of case study sites within national context. (B) Clyde basin, west-central Scotland. White line marks the area included in the geological model described in Finlayson (2012). (C) Cromarty Firth, northeast Scotland. (D) Drumlinised terrain in southwest Glasgow. Images derived from ETOPO1 Global Relief Model (A) and Intermap Technologies NEXTMap Britain elevation data (B,C,D). Coordinates in B, C, and D in British National Grid.

Fig. 2. (A) Removal of $2.37 \mathrm{~km}^{2}$ of postglacial sediments in the Clyde basin reveals interpolated former glacier bed. (B) Location of boreholes and cross section lines used to control interpolations in the model described by Finlayson (2012). (C) Distance from modern land surface to the former glacier bed. Dashed white line shows interpreted margin of outlet glacier at the time when the Blantyreferme moraine was formed.

Fig. 3. (A) Location of boreholes (red) and position of cross section (black line) in the Cromarty Firth, northeast Scotland. Hill-shaded digital surface model built from Intermap Technologies NEXTMap Britain elevation data. (B) Cross sectional line showing the thickness of postglacial sediments. x 10 vertical exaggeration. (C) Reconstructed cross section areas for a calving glacier in the Cromarty Firth, based on the modern seabed surface and the interpolated former glacier bed.

Fig. 4. Modern DSM, draped with surface geology, showing location of boreholes and surface data points used for ordinary kriging, southwest Glasgow. The modern land surface and interpolated former glacier bed are shown on the right-hand side. Kriging variance gives an indication of potential error that may be expected for the interpolated surface and is largely influenced by distance to nearest data point.

Fig. 5. (A) Shape factors calculated for six cross-valley profiles in the lower Clyde basin, using the modern land surface $(\mathrm{M})$ and the interpolated former glacier bed $(\mathrm{G})$. White arrow denotes the ice flowline shown in B, C, D, and E. Hill-shaded digital surface model built from Intermap Technologies NEXTMap Britain elevation data. Inset: example of both surfaces across profile 4. (B) Reconstructed ice surface elevations using the modern land surface 
and the interpolated former glacier bed. (C) Reconstructed ice thickness, using the modern land surface and the interpolated former glacier bed. (D) Comparison of reconstructed ice thickness, calculated using the modern land surface and the interpolated former glacier bed. (E) Comparison of reconstructed ice surface elevations, calculated using the modern land surface and the interpolated former glacier bed.

Fig. 6. Slope models used to aid identification of drumlin perimeters for the modern land surface and for the interpolated former glacier bed, southwest Glasgow. The drumlins are shown as individual solid objects on the right hand side. Note that only those drumlins with their entire perimeter falling within the study area were included. 
Tables

Table 1: Characteristics of calving margin, reconstructed from the modern land surface and from the interpolated former glacier bed

\begin{tabular}{llll} 
Surface & Width-averaged calving speed $\left(\mathrm{m} \mathrm{a}^{-1}\right)$ & Cross sectional area $\left(\mathrm{km}^{2}\right)$ & Steady-state flux $\left(\mathrm{km}^{3} \mathrm{a}^{-1}\right)$ \\
\hline \hline Modern & 283 & 0.15 & 0.043 \\
Glacier bed & 494 & 0.3 & 0.148 \\
\hline
\end{tabular}


Table 2: Characteristics of drumlins in southwest Glasgow, measured using the modern land surface (M) and the interpolated former glacier bed $(\mathrm{G})$.

\begin{tabular}{lllllll} 
Drumlin & Length $(\mathrm{m})$ & Width $(\mathrm{m})$ & Elongation ratio & Height $(\mathrm{m})$ & Area $\left(\mathrm{m}^{2}\right)$ & Volume $\left(\mathrm{m}^{3}\right)$ \\
\hline \hline 1: $\mathrm{M}$ & 700 & 431 & 1.62 & 27.1 & 235856 & 1778684 \\
1: G & 730 & 477 & 1.53 & 32.7 & 291131 & 2719984 \\
2: M & 734 & 460 & 1.60 & 22.6 & 287120 & 1826651 \\
2: G & 895 & 600 & 1.49 & 29 & 442955 & 4002971 \\
3: $\mathrm{M}$ & 637 & 482 & 1.32 & 20.1 & 239769 & 1518055 \\
3: G & 900 & 568 & 1.58 & 20.4 & 390160 & 2096181 \\
4: M & 775 & 657 & 1.18 & 25.2 & 404264 & 2905079 \\
4: G & 1085 & 661 & 1.64 & 30 & 538266 & 4002242 \\
5: M & 625 & 450 & 1.39 & 37 & 227835 & 2541572 \\
5: G & 625 & 450 & 1.39 & 37 & 227835 & 2541572
\end{tabular}



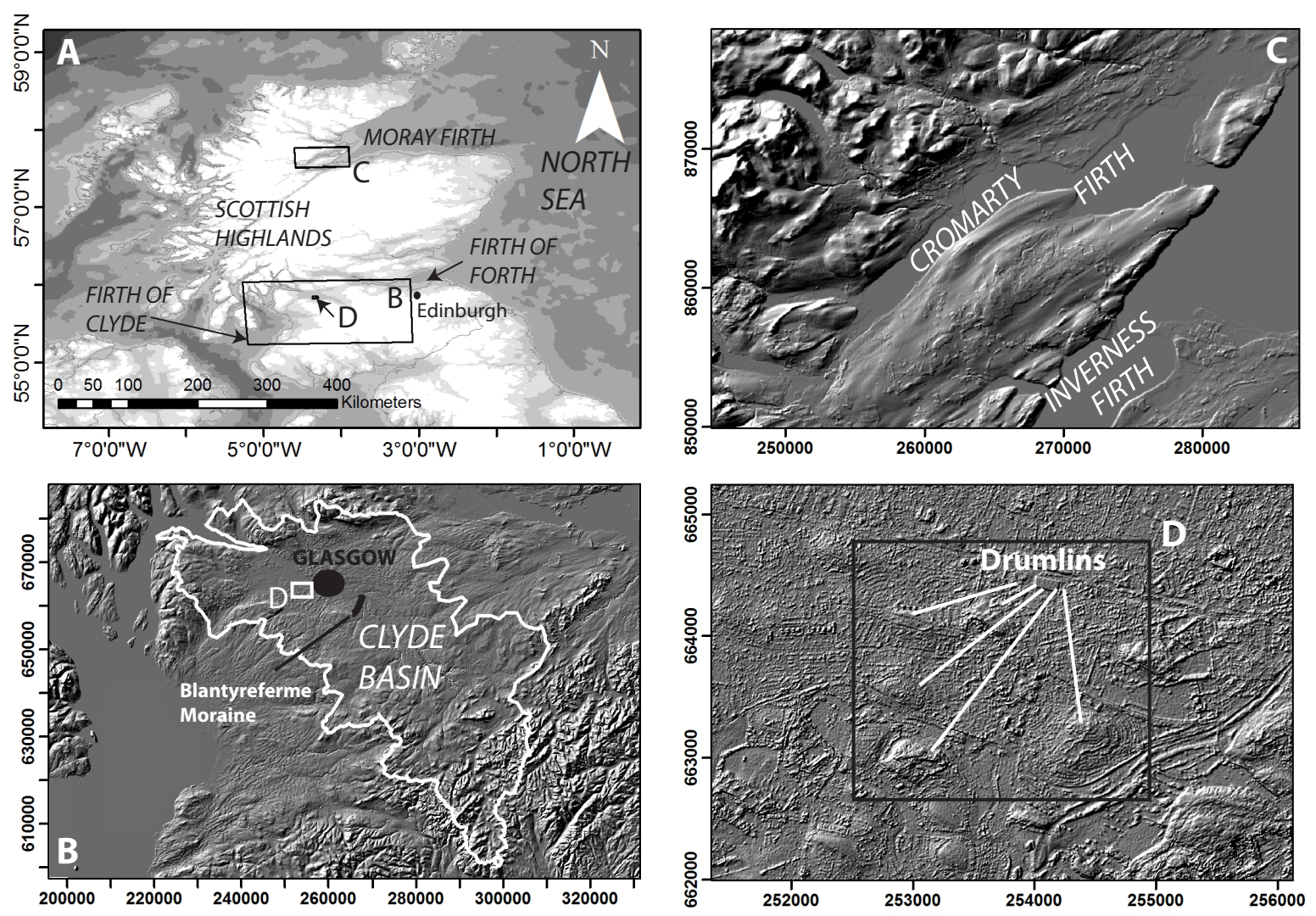

Figure 1: 

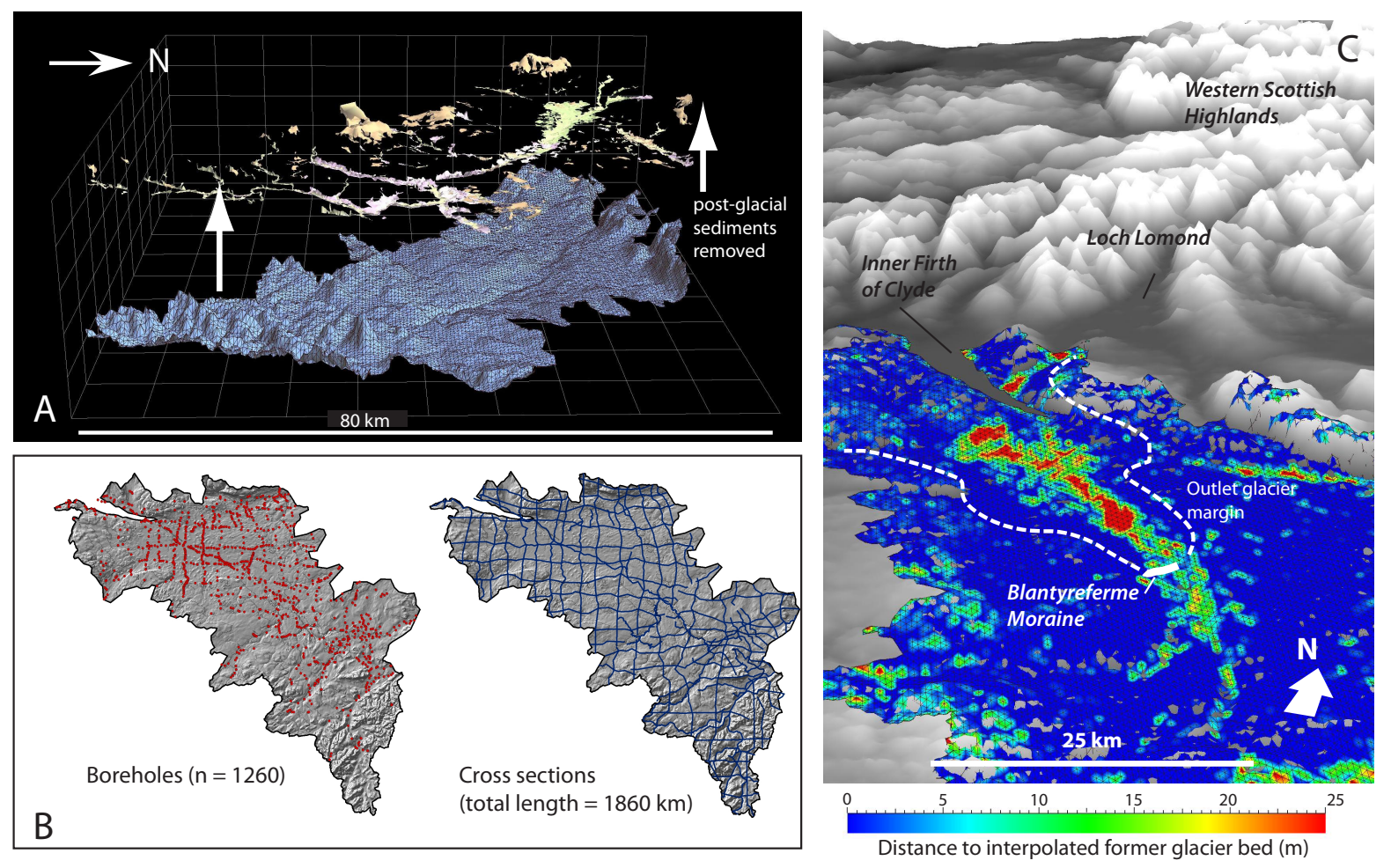

Figure 2: 

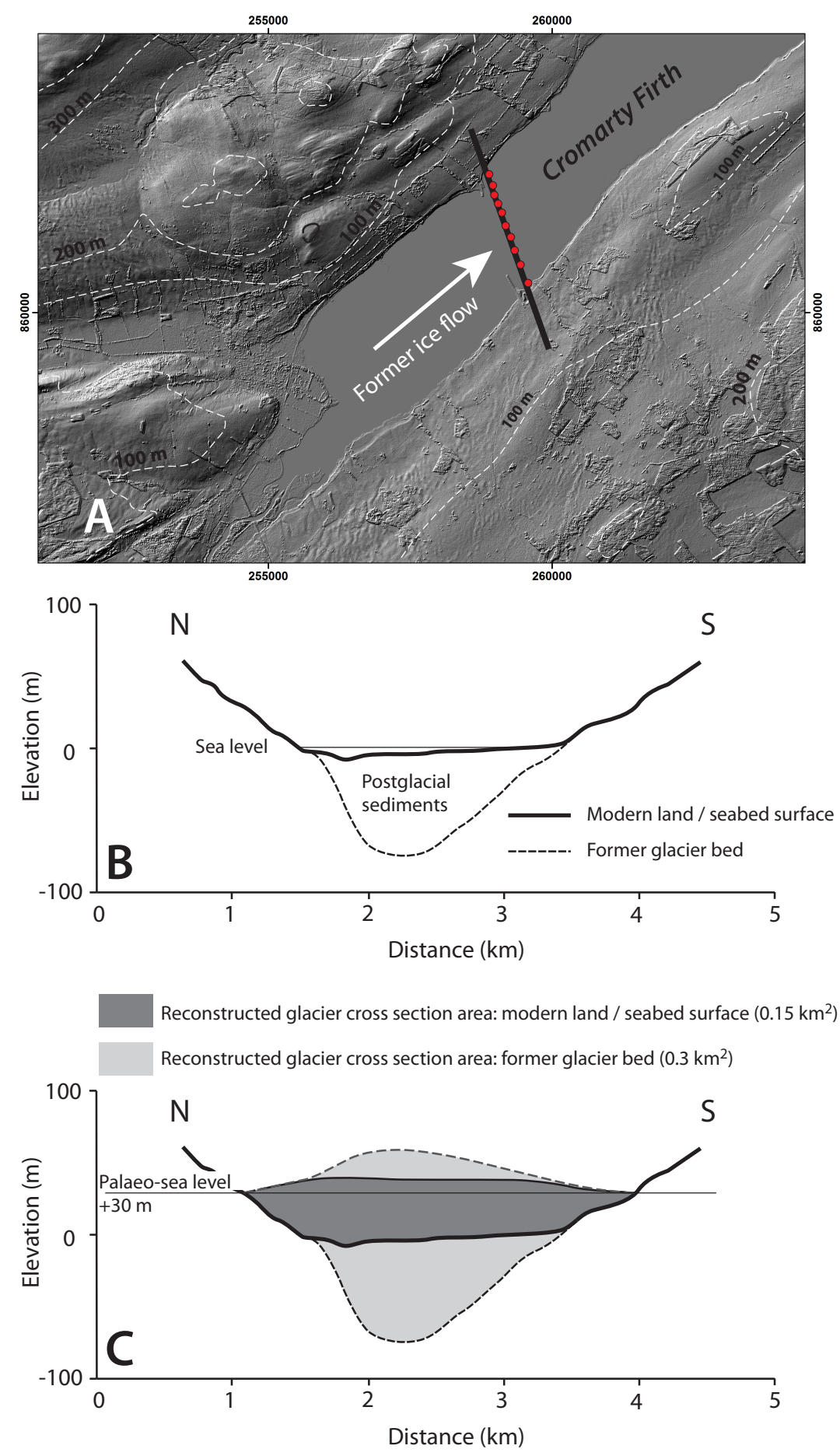

Figure 3: 


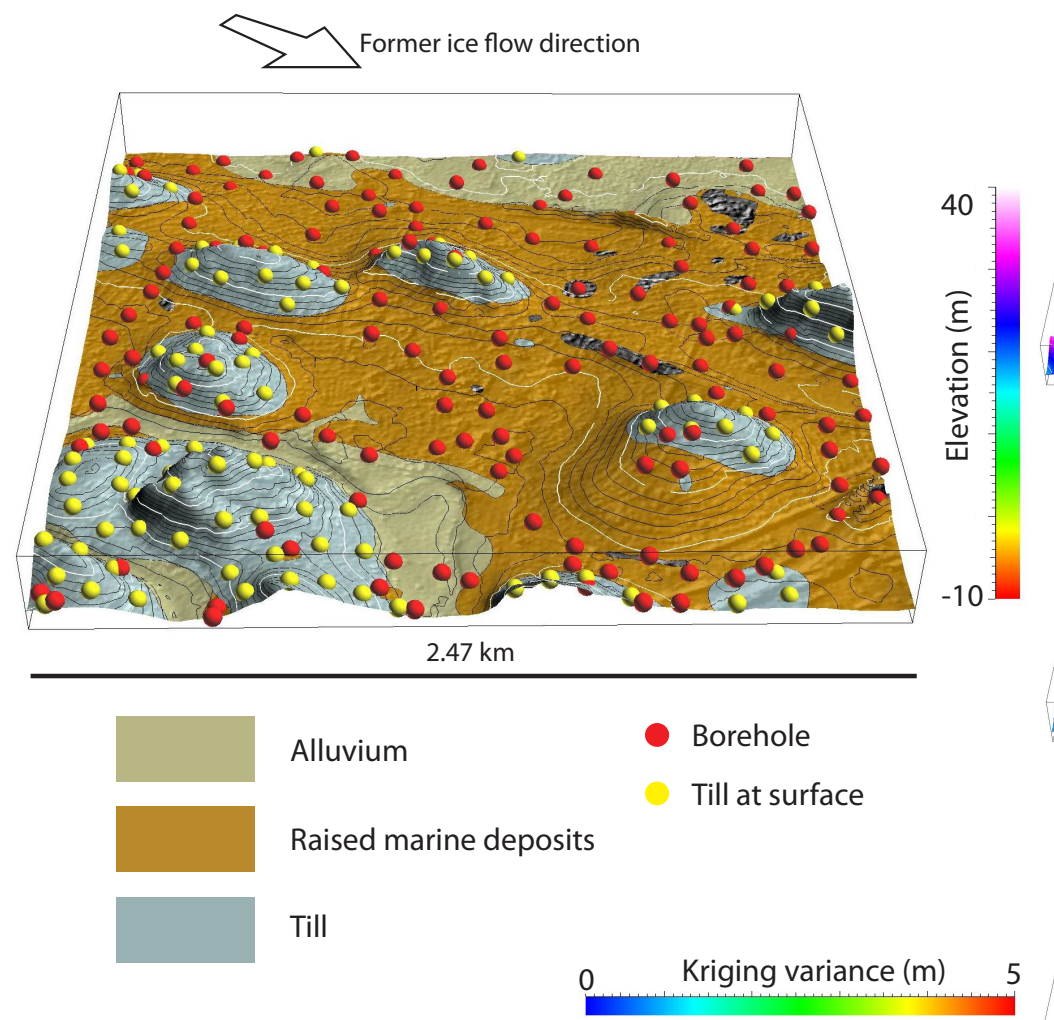

Modern surface DSM: 6.145 km²

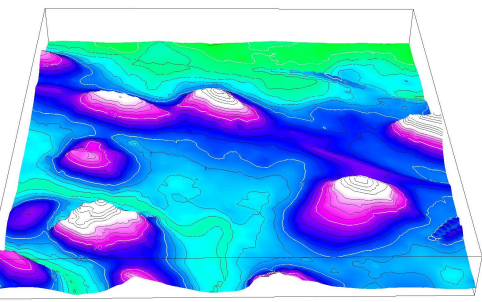

Former glacier bed DSM: $6.162 \mathrm{~km}^{2}$
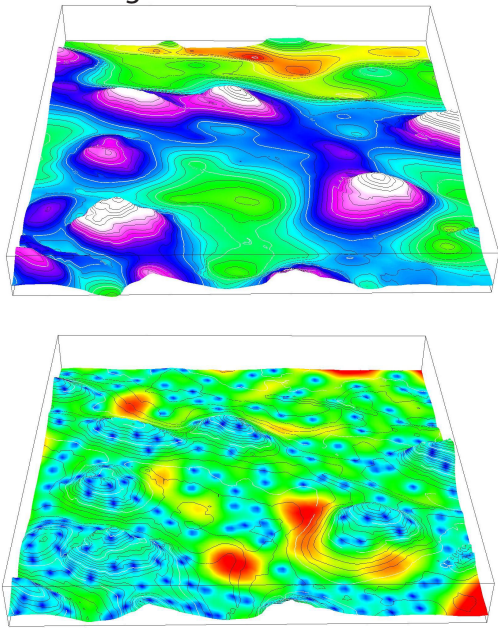

Figure 4: 

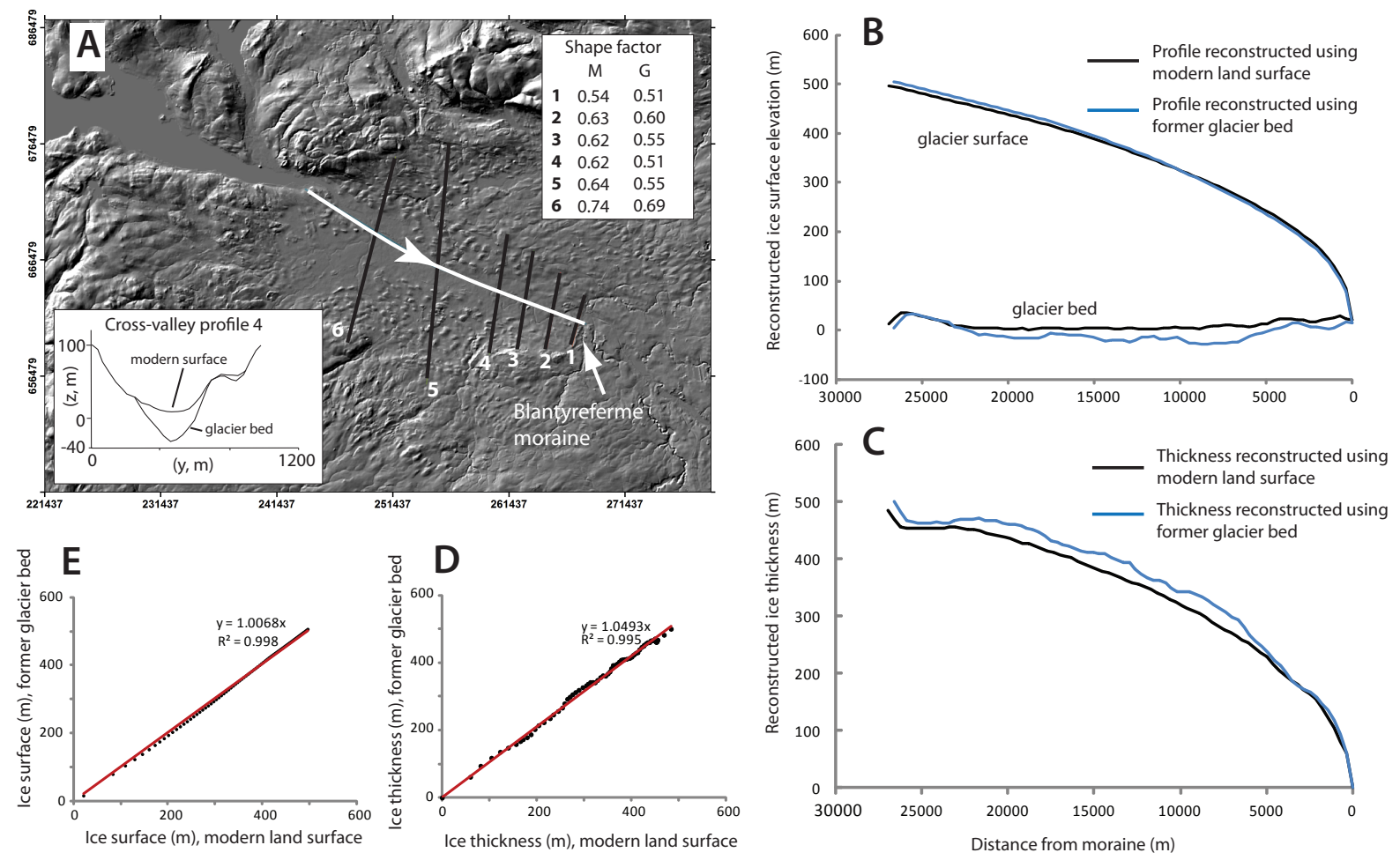

Figure 5: 


\section{$\checkmark$ Former ice flow direction}
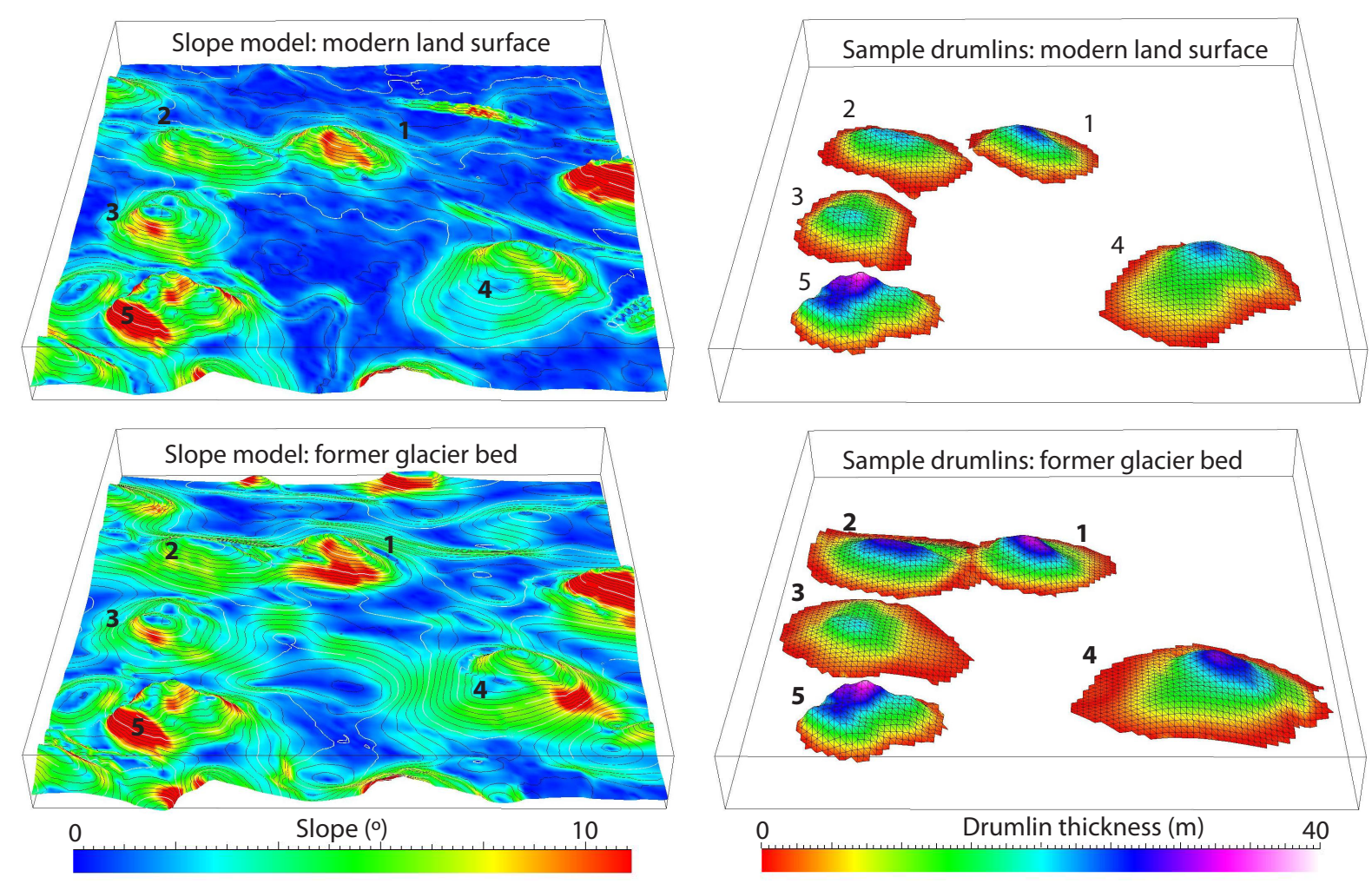

Figure 6: 